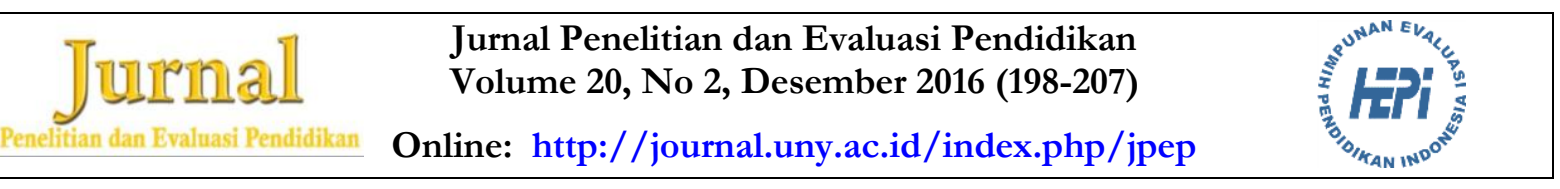

\title{
PENGEMBANGAN SOAL MATEMATIKA MODEL PISA MENGGUNAKAN KONTEKS JAMBI
}

\author{
Ninik Charmila ${ }^{*}$, Zulkardi ${ }^{1}$, Darmawijoyo ${ }^{1}$ \\ ${ }^{1}$ Universitas Sriwijaya \\ ${ }^{1}$ J1. Srijaya Negara Bukit Besar, Palembang, 30128, Sumatera Selatan, Indonesia \\ * Corresponding Author. Email: ninikcharmila7@gmail.com
}

\begin{abstract}
Abstrak
Penelitian ini bertujuan untuk menghasilkan soal matematika model PISA untuk siswa SMP menggunakan konteks Jambi yang valid, praktis, dan memiliki efek potensial. Metode penelitian yang digunakan adalah Design research tipe development study. Analisis data adalah analisis deskriptif. Hasil penelitian berupa seperangkat soal matematika model PISA menggunakan konteks Jambi yang valid, praktis dan memlilki efek potensial sebanyak 14 butir soal. Valid dari segi konten, konstruk, dan bahasa berdasarkan penilaian validator, praktis berdasarkan uji coba small group dan memiliki efek potensial berdasarkan analisis hasil jawaban siswa dan angket pada field test. Bedasarkan hasil analisis diperoleh bahwa soal yang dikembangkan memiliki beberapa efek potensial, yaitu memunculkan pelibatan kemampuan dasar matematis yang beragam pada proses penyelesaiannya. Selain itu, juga mampu menarik minat dan memotivasi siswa sehingga tertantang menyelesaikan soal. Soal-soal ini juga memberikan stimulus kepada siswa untuk berpikir kritis menggunakan penalaran sendiri dalam penyelesaiannya.
\end{abstract}

Kata kunci: research and development, development study, PIS A, Konteks Jambi

\section{DEVELOPING MATHEMATIC QUESTIONS OF PISA MODEL BY USING JAMBI CONTEXT}

\begin{abstract}
The aim of this research was to provide valid, practical mathematic questions of PISA model for SMP students by using Jambi contex, and have potential effect. The method of the research was developmental research design. Descriptive analysis was used to analyze the data. The result of the research was a set of valid, practical 14 mathematic questions of PISA model in Jambi contex, and having potential effect. The validity of content, construct, and language was based on expert judgment, the practicality was measured in small group, and the potential effect was based on analysis of student answers and questionnaires in field test. The result of analysis showed that the developed questions had several potential effects such as inviting students' various basic skills of mathematic in the process of answering the questions. Besides that, it could encourage students' ability and motivate students to answer and finish the questions. These questions also attract the students to use their critical thinking ability to answer the questions.
\end{abstract}

Keywords: research and development, development study, PIS A, Jambi context

Permalink/DOI: bttp://dx.doi.org/10.21831/pep.v20i2.7444 


\section{Pendahuluan}

Literasi matematika merupakan hal yang sangat penting. Hal ini dikarenakan literasi matematika menekankan pada kemampuan siswa untuk menganalisis, memberi alasan dan mengomunikasikan ide secara efektif pada pecahan masalah matematis yang mereka temui (OECD, 2009a, p.19). Hal inilah yang menghubungkan matematika yang dipelajari di ruang kelas dengan berbagai macam situasi dunia nyata.

Menurut OECD (2012, p.17) literasi matematika adalah kemampuan individu untuk merumuskan, menerapkan, dan menafsirkan matematika dalam berbagai konteks. Dalam hal ini termasuk penalaran matematis dan menggunakan konsep matematika, prosedur, fakta dan alat matematika untuk mendeskripsikan, menjelaskan dan memprediksi fenomena/kejadian. Dengan demikian, literasi matematika diharapkan dapat menjadikan individu benar-benar memahami peran matematika dalam kehidupan modern yang dihadapinya di masa yang akan datang dalam berbagai situasi yang ditemui.

Salah satu program yang menilai literasi matematika adalah Program for International Student Assesment (PISA). Negara Indonesia telah beberapa kali mengikuti survei ini. Walaupun demikian, hasil PISA matematika Indonesia masih tergolong rendah. $\mathrm{Hal}$ ini terlihat dari peringkat yang dicapai Indonesia. Sejak tahun 2006 hingga 2012 peringkat PISA matematika Indonesia terus menurun. Peringkat terendah diperoleh Indonesia pada tahun 2012, yaitu peringkat 64 dari 65 negara yang berpartisipasi dalam PISA matematika (Stacey et al., 2015). Selain itu, hasil survey PISA pada tahun 20032009 menunjukkan bahwa hampir 80\% siswa Indonesia berada di bawah dasar level 2 (Widjaja, 2011, p.70). Padahal ada 6 level soal yang diujikan dalam PISA tersebut.

Rendahnya prestasi siswa Indonesia dalam PISA matematika dapat dipengaruhi oleh berbagai hal. Salah satu hal yang dapat dilakukan untuk mengatasinya adalah dengan membiasakan siswa berlatih soal-soal model PISA. Pembiasaan ini dapat dimulai dari pembelajaran di kelas. Oleh karena itu, perlu dikembangkan soal-soal setara PISA dengan konteks Indonesia baik oleh guru, peneliti, ataupun mahasiswa yang sedang menyelesaikan tugas akhir (Johar, 2012, p. 39). Berkaitan dengan hal ini, Kohar (2014b) menyatakan bahwa salah satu cara membantu guru untuk melaksanakan pembelajaran berbasis soal PISA, dengan tujuan membiasakan siswa adalah dengan menyediakan bank soal model PISA.

Selain pembiasaan menggunakan soal model PISA dalam pembelajaran, penggunaan konteks juga dinilai sangat penting. Hal ini dilakukan agar dalam pembelajaran siswa dapat termotivasi dalam mempelajari matematika (Widjaja, 2013, p.151). Seiring dengan meningkatnya motivasi siswa diharapkan akan meningkatkan hasil belajarnya.

Selain itu, The Cornerstone of Tech Prep (1999, p.1) menyatakan belajar menggunakan konteks menjadikan siswa menemukan hubungan bermakna antara ide-ide abstrak dan aplikasi praktis dalam konteks dunia nyata. Selain itu, penggunaan konteks lokal dapat membantu siswa memahami fenomena matematika dari perspektif pengalaman hidup mereka sendiri. Hal ini menjadikan matematika jauh lebih menarik dan bermanfaat bagi semua siswa (UNESCO, 2008, p.19).

Berkaitan dengan hal ini, hasil penelitian di Hong Kong mendapati bahwa itemitem TIMSS dan PISA sering digunakan dalam studi penelitian tes pencapaian matematika. Namun demikian, sangat disayangkan pengembangan item tes berbasis konteks dalam kearifan lokal masih kurang (Leung, Chan, Tang, \& Chan, 2009, p.47). Jablonka (dikutip oleh Lange, 2007, p.112) menyatakan bahwa sebuah konteks dapat menjadi familiar bagi beberapa siswa tetapi tidak untuk yang lain. Hal ini menyebabkan penggunaan konteks yang belum dikenal siswa dalam sebuah pembelajaran dan instrumen penilaian akan dapat menghilangkan fungsi konteks itu sendiri. Dengan demikian, penting untuk mengintegrasikan konteks di lingkungan sekitar tempat suatu pembelajaran berlangsung ke dalam pem- 
belajaran, termasuk dalam kegiatan penilaiannya. Berkaitan dengan hal ini, soal-soal kontekstual yang lebih terkait dengan kehidupan sehari-hari siswa di tempat tinggal mereka sangat menarik untuk mengaktifkan siswa dalam pembelajaran. Soal-soal seperti ini juga akan menantang proses berpikir matematis siswa (Kadir \& Masi, 2013, p.788).

Beberapa penelitian tentang pengembangan soal PISA yang telah dilakukan di antaranya berjudul Pengembangan Soal Matematika Model PISA Berbasis Online yang ditulis oleh I Ketut Kertayasa (Kertayasa, 2014, pp.162-171). Selain itu, terdapat pula Pengembangan Soal Model PISA untuk Mengetahui Profil Literasi Matematis Siswa SMA yang ditulis oleh Ahmad Wachidul Kohar (Kohar, 2014a, pp.14-26). Selanjutnya Ambarsari Kusuma Wardani juga menulis jurnal yang berjudul Pengembangan Soal Matematika Model PISA untuk Program Pengayaan Kelas VII SMP (Wardani, 2014, pp. 35-42). Hal ini menunjukkan bahwa banyak pihak tertarik dan menganggap pengembangan soal model PISA sangat perlu dilakukan. Meski demikian, belum ada yang mengembangkan soal PISA menggunakan konteks lokal, khususnya Jambi. Pada bahasan sebelumnya telah dijelaskan bahwa penting untuk mengintegrasikan konteks di lingkungan sekitar tempat suatu pembelajaran berlangsung ke dalam pembelajaran itu sendiri, termasuk dalam kegiatan penilaiannya.

Jambi merupakan salah satu provinsi di Indonesia. Konteks lokal Provinsi Jambi memiliki potensi yang beraneka ragam. Keanekaragaman ini dapat dijadikan sumber referensi dalam pembelajaran matematika di sekolah menggunakan konteks Jambi. Dalam ruang lingkup provinsi Jambi terdapat berbagai hal yang memuat konsepkonsep matematika termasuk konten matematika dalam PISA. Berdasarkan framework PISA matematika 2015, konten matematika dalam PISA terdiri dari perubahan dan hubungan, ruang dan bentuk, bilangan, serta ketidakpastian dan data (OECD, 2013, pp.16-19). Bermacam-macam konten yang lebih spesifik di dalamnya, seperti geometri, pola bilangan, aljabar, serta probabilitas dan ketidakpastian dan data terdapat dalam konteks Jambi. Hal ini dapat ditemukan pada lingkungan alam dan sosial, peninggalan sejarah dan perjalanan pembangunan Provinsi Jambi hingga saat ini. Di antaranya adalah motif batik Jambi, makanan khas Jambi, Taman Nasional Kerinci Sebelat (TNKS) dan sebagainya.

Berdasarkan uraian tersebut tujuan dari penelitian ini adalah mengembangkan soal matematika model PISA menggunakan konteks Jambi yang valid dan praktis serta memiliki efek potensial.

\section{Metode Penelitian}

Penelitian ini menggunakan Design research tipe development study. Tahapan pengembangan soal terdari tahap preliminary dan formative evaluation (Zulkardi, 2002, p. 20). Tahap formative evaluation terdiri dari tahap self evaluation, prototyping (expert review, one-to-one, dan small group), dan field test (Tessmer, 1998, p. 35).

Pada tahap preliminary, peneliti melakukan analisis siswa, analisis kurikulum untuk SMP, dan analisis soal-soal PISA. Kemudian peneliti mendesain perangkat soal meliputi kisi-kisi soal dan butir soal matematika model PISA menggunakan konteks Jambi. Perangkat yang dihasilkan pada tahap ini dinamakan prototype awal. Kemudian pada prototype awal ini dilakukan tahap formative evaluation.

Tahap pertama yang dilakukan pada formative evaluation ini adalah self evaluation. Perangkat soal yang telah dibuat dievaluasi sendiri oleh peneliti. Dalam hal ini penulis mendapat bantuan dari beberapa orang teman sejawat yang telah berpengalaman dalam pengembangan soal-soal PISA ataupun yang mengetahui seluk beluk siswa yang akan menjadi subjek penelitian. Hasil dari self evaluation ini disebut prototype 1. Langkah selanjutnya yang dilakukan terhadap prototype 1 adalah prototyping. Diawali dengan expert reviews dan one-to-one yang dilakukan secara paralel. Tahap expert reviews merupakan pengujian validitas butir soal oleh pakar (expert). Hal ini dilakukan dengan 
cara mencermati dan menilai setiap butir soal berdasarkan konten, konstruk, dan bahasa. Konten yang dinilai adalah kesesuaian dengan kurikulum yang digunakan dan materi yang dipelajari siswa tingkat SMP. Konstruk yang dicermati adalah kesesuaian dengan karakteristik soal PISA. Validasi bahasa yang dimaksud adalah kesesuaian penggunaan bahasa pada butir soal dengan kaidah bahasa yang berlaku (EYD). Saran dan komentar yang disampaikan oleh validator dijadikan sebagai masukan untuk revisi prototype 1.

Bersamaan dengan validasi oleh para ahli, dilakukan tahap one-to-one. Tahap ini melibatkan tiga orang siswa dengan kemampuan beragam (rendah, sedang, dan tinggi). Siswa diminta untuk membaca dan mencermati soal kemudian memberi tanggapan tentang keterbacaan dan kejelasan maksud soal. Temuan yang diperoleh pada tahap expert reviews dan one-to-one digunakan dalam merevisi prototype 1. Hasil dari revisi prototype 1 ini adalah prototype 2. Selanjutnya, prototype 2 diujikan kepada siswa di tahap small group. Tahap ini melibatkan enam orang siswa dengan kemampuan beragam untuk menyelesaikan soal-soal prototype 2. Kemudian, para siswa juga diminta pendapat dan komentar mengenai soal yang telah mereka kerjakan. Tahap ini berfokus pada kepraktisan soalsoal yang telah dikembangkan. Temuan pada tahap small group digunakan sebagai revisi prototipe 2 menjadi prototype 3 .

Tahap penelitian selanjutnya adalah field test. Pada tahap ini prototype 3 yang telah dihasilkan diujicobakan pada satu kelas siswa berjumlah 32 orang siswa kelas IX SMP Negeri 3 Kabupaten Tebo. Uji coba dilaksanakan pada semester ganjil tahun ajaran 2015/2016. Hasil field test berupa lembar jawaban siswa yang kemudian dianalisis secara deskriptif untuk mengetahui efek potensial yang dihasilkan dari soal model PISA menggunakan konteks Jambi yang telah dikembangkan dan melalui proses validasi.

Instrumen yang digunakan dalam penelitian ini berupa lembar validasi dan tes. Lembar validasi digunakan pada saat proses validasi oleh para ahli, sedangkan instrumen tes digunakan untuk memperoleh informasi mengenai kepraktisan soal yang dikembangkan dan mengetahui efek potensialnya.

\section{Hasil Penelitian dan Pembahasan}

Hasil Penelitian

\section{Tahap Preliminary}

Pada tahap ini penulis melakukan analisis terhadap siswa, kurikulum SMP, dan soal-soal PISA. Kemudian dihasilkan kisikisi, profil soal, dan soal matematika model PISA menggunakan konteks Jambi. Setelah perangkat soal dihasilkan maka selanjutnya dilakukan self evaluation. Hasil dari self evaImation adalah prototype 1 yang terdiri dari 14 soal matematika model PISA menggunakan konteks Jambi. Selanjutnya, perangkat soal memasuki tahap expert reviews bersamaan dengan one-to-one.

\section{Expert Reviews}

Tahap ini melibatkan dua ahli sebagai validator, yaitu dosen matematika Universitas Negeri Medan dan dosen matematika Universitas Jambi. Berdasarkan pencermatan validator, diperoleh kesimpulan bahwa soal matematika model PISA menggunaka konteks Jambi telah memenuhi indikator valid dari segi konten, konstruk, dan bahasa. Walaupun demikian, masih dilakukan revisi pada prototype 1 atas dasar komentar dan saran dari para ahli.

\section{One-to-one}

Sejalan dengan pelaksanaan validasi oleh para ahli, dilakukan tahap one-to-one. Pada tahap ini ada tiga orang siswa SMP Negeri 3 Jambi yang dilibatkan. Siswa diminta membaca dan mencermati soal. Hal ini dilakukan agar peneliti dapat mengamati respon dan kendala yang dihadapi siswa. Respon dan kendala yang diamati berfokus pada keterbacaan dan kejelasan maksud soal. Setelah itu para siswa dimintai pendapat dan komentar mengenai setiap butir soal.

Komentar ini dijadikan pertimbangan bagi revisi yang dilakukan pada prototype 1 . Selanjutnya hasil revisi pada prototype 1 
menghasilkan prototype 2 yang diujikan pada tahap small group.

\section{Small Group}

Tahap ini melibat 6 orang siswa. Siswa diminta mencermati butir-butir soal dan memberikan komentar terhadap soal yang telah mereka selesaikan. Hasil yang dilihat adalah kepraktisan setiap butir soal bagi siswa. dalam pelaksanaannya, secara umum semua soal telah dapat dipahami dan diselesaikan, hanya ada beberapa soal yang masih perlu direvisi karena pada awalnya masih menimbulkan penafsiran yang berbeda dari maksud soal yang sebenarnya. Dari temuan ini dilakukan revisi prototype 2 menjadi prototype 3 yang digunakan pada tahap ahhir, yaitu field test.

\section{Field Test}

Pada tahap ini perangkat soal prototype 3 diujikan kepada siswa kelas IX A SMP Negeri 3 Kabupaten Tebo. Sebanyak 14 butir soal ini dikerjakan dalam waktu 120 menit. Dalam mengerjakan soal ini, siswa diminta menuliskan strategi penyelesaian yang dipilihnya. Dokumen hasil dari field test berupa lembar jawaban siswa dan lembar angket mengenai soal pada prototype 3 . Fokus dari field test ini adalah untuk melihat efek potensial soal yang telah dikembangkan.

\section{Pembahasan}

Prototype 3 yang dihasilkan pada penelitian ini berupa seperangkat soal matematika model PISA menggunakan konteks Jambi untuk tingkat SMP sebanyak 14 butir soal. Soal ini terdiri dari terdiri dari 5 soal konten bilangan, 1 soal konten ruang dan bentuk, 4 soal konten perubahan dan hubungan, dan 4 soal konten ketidakpastian dan data. Berdasarkan konteks matematika dalam PISA soal ini terdiri dari 3 soal konteks pribadi, 5 soal konteks pekerjaan, 5 soal konteks umum, dan satu soal konteks ilmiah. Jika ditinjau berdasarkan prediksi level soal dalam PISA, soal ini terdiri atas 1 butir soal level 1, 1 butir soal level 2, 6 butir soal level 3, 3 butir soal level 4, 2 butir soal level 5, dan 1 butir soal level 6. Level butir soal menyesuaikan butir soal dalam PISA.

Berikut ini disajikan beberapa pembahasan jawaban siswa yang diperoleh pada saat field test. Soal pertama yang akan dibahas adalah soal nomor satu dengan konteks motif batik Jambi. Konteks motif batik Jambi ini dipilih karena batik Jambi sangat dekat dengan keseharian siswa. Bahkan, pada hari-hari tertentu di sekolah para siswa memakai seragam yang bermotif batik Jambi. Penulis bermaksud memunculkan literasi matematika siswa yang berkaitan dengan salah satu hal paling dekat dengan keseharian mereka. Dalam ketegori soal-soal PISA, soal ini termasuk dalam konten bilangan yang berkaitan dengan pola barisan bilangan. Konteks pada soal ini tergolong kedalam konteks pribadi. Proses dalam matematika yang terjadi dalam penyelesaiannya adalah menerapkan konsep pola bilangan dalam kehidupan sehari-hari. Selanjutnya prediksi level soal nomor 1 ini adalah level 4. Soal nomor satu ditampilkan pada Gambar 1.

Soal tersebut dikembangkan dengan tujuan untuk mangaktifkan kemampuan bernalar siswa yang juga melibatkan kemampuan-kemampuan lainnya. Penalaran ini dimulai dari pengamatan motif batik secara nyata (melalui beberapa bantuan gambar potongan kain bermotif batik Jambi). Pengamatan ini diharapkan akan mencapai kesimpulan bahwa bilangan-bilangan yang ditemukan membentuk pola tertentu dengan selisih tetap. Akan ada dua pola barisan berpola, yaitu pada motif kapal sanggat dan pada motif burung angsa. Dari pola-pola inilah nantinya akan dapat digunakan untuk menentukan banyak motif burung angsa dan kapal sanggat pada potongan-potongan yang diminta dalam tabel yang telah disediakan. Penyelesaian soal nomor 1 ini, juga dapat dilakukan dengan menen-tukan banyak motif yang ditentukan dengan menyelidiki selisih dari tiap potongan yang berurutan dari gambar pada setiap motif. Jawaban ini dapat ditemukan meskipun tanpa menentukan bentuk umum dari pola barisan yang ditemukan. 
Berikut ditampilkan pada Gambar 2 salah satu jawaban siswa pada soal nomor 1 yang dibahas dalam penelitian ini. Jawaban berikut adalah milik Siswa I (S1).

\section{MOTIF BATIK JAMBI}

Puti Dayang Indah membuat potongan-potongan kain dari sehelai kain batik Jambi. Ia memotong kain dengan rapi dan teratur. Beberapa potongan yang dibuatnya tampak seperti gambar berikut ini.

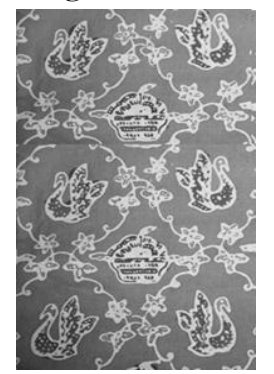

Potongan 1

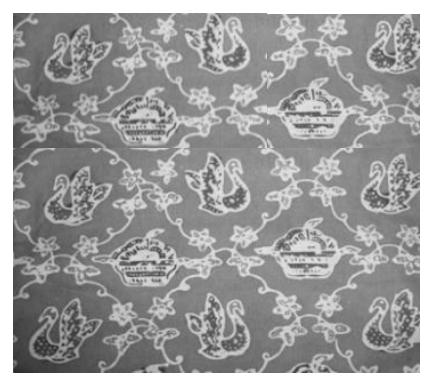

Potongan 2

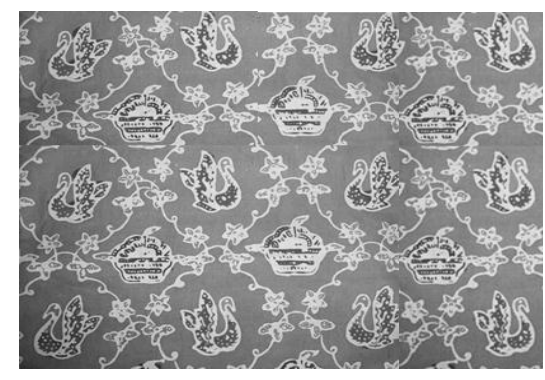

Potongan 3

Keterangan motif batik:

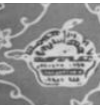

$=$ Motif Kapal Sanggat

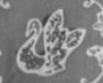

$=$ Motif Burung Angsa

Sumber: http://budaya-indonesia.org/f/1173/

Pertanyaan 1 (Soal Nomor 1)

Lengkapilah tabel di bawah ini:

\begin{tabular}{|c|c|c|}
\hline Potongan Ke- & Banyak Motif Kapal Sanggat & Banyak Motif Burung Angsa \\
\hline 1 & 2 & 6 \\
\hline 2 & 4 & $\ldots$ \\
\hline 3 & $\ldots$ & $\ldots$ \\
\hline 4 & $\ldots$ & $\ldots$ \\
\hline 7 & $\ldots$ & $\ldots$ \\
\hline 10 & $\ldots$ & $\ldots$ \\
\hline
\end{tabular}

Gambar 1. Soal Nomor 1 pada Prototype 3

\begin{tabular}{|c|c|c|c|c|}
\hline \multicolumn{5}{|c|}{$\begin{array}{l}\text { Pada potongan ke } 1 \text { adalar } \\
\text { Setisih antara Bangak metif kapal sanggat don hanyak motif } \\
\text { Buning Angsa pada porongan I adalah 4, pada potongan } \\
\text { kedua adalah 5, sedangkan pada potengan ke } 3 \text { adalah } 6 \text {, }\end{array}$} \\
\hline Potongan Xe- & Banyak M & otif kapal Sanggat & Banyak Motif Burung Angsa & $\begin{array}{l}\text { dengan } \\
\text { menambahtan }\end{array}$ \\
\hline 1 & & 2 & 6 & banyeik motif \\
\hline 2 & & 4 & 4 & $\begin{array}{l}\text { Kapal sanggat } \\
\text { dengan sellsith }\end{array}$ \\
\hline 3 & & $G$ & 12 & Potongan sesuai \\
\hline 4 & & 8 & 15 & $\begin{array}{l}\text { petengan } \\
\text { pisalnya }\end{array}$ \\
\hline 7 & & 14 & 34 & $\begin{array}{l}\text { ke } 4 \text { banyal } \\
\text { motif } 8 \text {, maka }\end{array}$ \\
\hline 10 & & 20 & 23 & Banyak burung \\
\hline
\end{tabular}

Gambar 2. Jawaban soal nomor 1 pada Prototype 3 oleh Siswa I 
Pada jawaban yang disajikan pada Gambar 2 tersebut, dapat dilihat bahwa Siswa I melibatkan penalaran dan argumentasi yang cukup tinggi dalam penyelesaian soal. Akan tetapi, operasi matematika yang dilibatkannya cukup sederhana. Siswa tersebut tidak menggunakan matematisasi yang melibatkan simbol-simbol saat menjawab soal ini. Selain itu, S1 juga melibatkan kemampuan komunikasi dalam menjelaskan strategi penyelesaian yang ditempuhnya. Dengan menggunakan cara tersebut dalam penyelesaian soal nomor 1 ini, siswa sudah menggunakan cara penalaran dengan alur berpikir yang dibuatnya sendiri. Penalaran merupakan suatu proses berpikir dalam pencapaian sebuah kesimpulan dari suatu pengetahuan yang di hadapi dengan cara mengaitkannya dengan pengetahuan yang telah dimiliki sebelumnya (Rizta, Zulkardi, \& Hartono, 2013, p. 231). Dalam hal ini S1 mengaitkan dua pola barisan yang ditemuinya dalam soal dengan pengetahuan mengenai konsep pola barisan yang telah dimilki sebelumnya. Ia mendapatkan kesimpulan bahwa barisan bilangan yang terbentuk dari selisih Motif Kapal Sanggat dan Motif Burung Angsa memiliki suku pertama 4 dan beda 1 . Dengan cara ini ia melengkapi tabel pada soal nomor satu. Langkah yang ditempuh inijuga sudah menunjukkan bahwa siswa melibatkan proses berpikir kritis. Pada empat tahap berpikir kritis yang dikemukakan oleh Kurniasih (2011, p. 646), tahap berpikir ini termasuk ke dalam tahap strategi/taktik yang melibatkan kegiatan penggunaan strategi berpikir yaitu penggunaan algoritma pemikiran yang diwujudkan dalam tindakan menyelesaikan masalah. Berdasarkan hal ini dapat disimpulkan bahwa soal nomor 1 telah memiliki efek potensial berupa pelibatan penalaran dan argumentasi serta beberapa kemampuan dasar matematis lain seperti komunikasi dan merancang strategi untuk pemecahan masalah juga proses berpikir kritis pada siswa.

Soal berikutnya yang akan dibahas pada artikel ini adalah soal nomor 9. Soal ini menggunakan konteks Gunung Kerinci. Konteks ini dipilih karena Gunung Kerinci merupakan gunung api tertinggi di Indonesia dan sangat terkenal hingga mancanegara. Konteks yang digunakan adalah jalur pendakian menuju Puncak Indrapura oleh satu tim pendaki yang penulis ambil dari salah salah satu situs internet. Dalam kategori soal-soal PISA, soal ini termasuk ke dalam konten perubahan dan hubungan. Untuk konteks, soal ini termasuk ke dalam soal yang menggunakan konteks umum. Proses matematika yang terjadi dalam penyelesaiannya adalah menerapkan, yaitu menerapkan konsep kecepatan rata-rata dari empat perjalanan dengan diketahui jarak tempuh dan waktu yang diperlukan berdasarkan gambar. Selanjutnya, prediksi level soal ini adalah level 4. Soal nomor 9 ditampilkan pada Gambar 3.

Untuk menyelesaikan soal ini, KDM yang paling dominan digunakan adalah penalaran dan argumentasi yang digunakan dalam merancang strategi penyelesaian untuk masalah. Strategi ini dapat berupa matematisasi. Kemampuan representasi dan komunikasi juga dilibatkan untuk memilih dan mengidentifikasi elemen-elemen pada gambar yang akan digunakan dalam penyelesaian soal. Selain itu, operasi matematis juga banyak dilibatkan dalam penentuan jawabannya.

Berikut ditampilkan pada Gambar 4 salah satu jawaban siswa pada soal nomor 9 yang dibahas dalam penelitian ini. Jawaban ini adalah milik Siswa II (S2).

Siswa II telah melibatkan penalaran dan argumentasi dengan baik dalam merancang strategi penyelesaian masalah. Strategi ini disajikan dalam bentuk matematisasi yang tepat. Kemampuan komunikasi juga sudah dilibatkan dengan baik dalam memilih dan mengidentifikasi elemen-elemen yang akan digunakan dalam penyelesaian soal ini. Walaupun pada lembar jawaban ini siswa belum mendapatkan skor penuh, akan tetapi ia telah melibatkan beberapa kemampuan dasar matematika dalam penyelesainnya. Kemampuan lain yang dicermati adalah pelibatan proses berpikir kritis. Dalam hal ini siswa telah mencapai tahap penilaian yang meliputi memilih informasi/konsep/ 
ide yang relevan, menghubungkan antarinformasi/kode/ konsep itu, menghubungkan kembali dengan informasi/kode/konsep yang relevan, menghubungkan dengan masalah sebelumnya, dan menilai kegiatan penalaran (Kurniasih, 2011, p. 645). Berdasarkan hal ini dapat disimpulkan bahwa soal nomor 9 yang dikembangkan telah memiliki efek potensial berupa pelibatan penalaran dan argumentasi, perancangan strategi, ko- munikasi, representasi, dan berpikir kritis bagi siswa.

Selain lembar jawaban siswa, dokumen lain yang diperoleh angket. Berdasarkan hasil angket, diketahui bahwa siswa merasa tertarik, termotivasi, dan tetantang untuk menyelesaikan soal. Ketertarikan mereka terutama pada penggunaan konteks daerah Provinsi Jambi dalam pengembangan soal ini.

\section{GUNUNG KERINCI}

Gunung Kerinci merupakan gunung api tertinggi di Indonesia, 3.805 mdpl (meter di atas permukaan laut). Gunung ini termasuk ke dalam kawasan Taman Nasional Kerinci Seblat dan juga merupakan bagian dari pegunungan Bukit Barisan yang terletak di Kabupaten Kerinci, Provinsi Jambi.

Gunung Kerinci termasuk salah satu gunung yang digemari para pendaki dari Nusantara maupun mancanegara. Jalur pendakiannya beragam, bahkan terdapat jalur tanjakan dengan kemiringan mencapai 60 derajat. Jalur Kersik Tuo merupakan jalur umum yang banyak dipakai oleh para pendaki untuk mendaki ke puncak Gunung Kerinci.

Gambar di bawah ini merupakan jarak dan rata-rata waktu pendakian satu tim pendaki Gunung Kerinci melalui jalur Kersik Tuo.

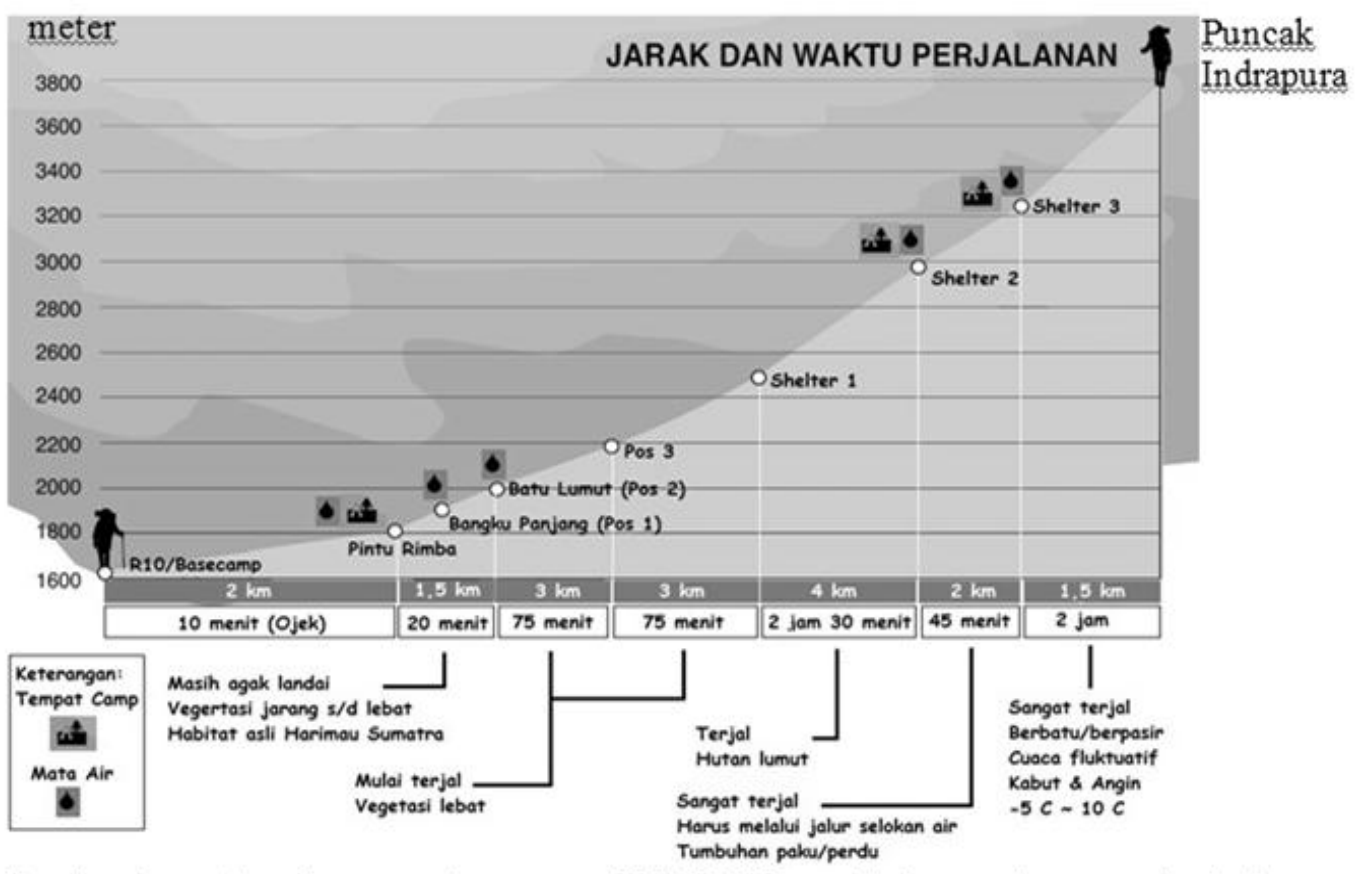

Sumber: https://gardjoew.wordpress.com/2014/04/10/my-third-summit-gunung-kerincimount-kerinci-3805-mdpl/

Pertanyaan 2 (Soal Nomor 9)

Perkirakanlah kecepatan rata-rata tim pendaki tersebut mulai dari Pos 3 hingga mencapai Puncak Indrapura. Nyatakan dalam km/jam.

Gambar 3. Soal Nomor 9 pada Prototype 3 


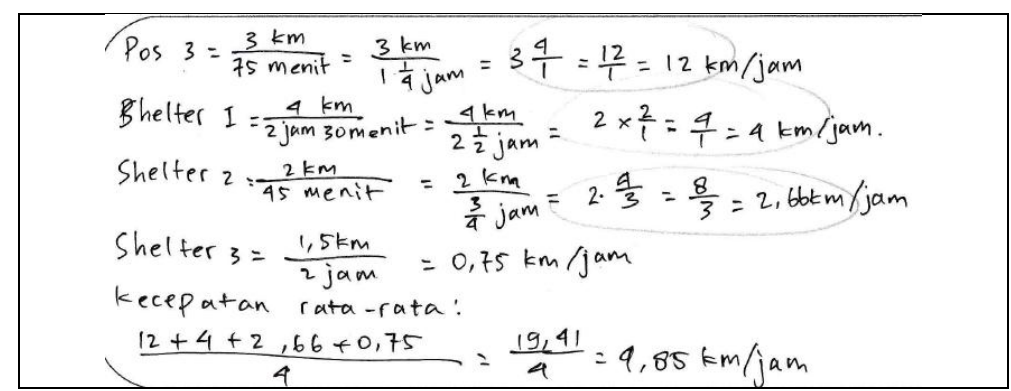

Gambar 4. Jawaban soal nomor 9 pada prototype 3 oleh Siswa II (S2)

\section{Simpulan}

Berdasarkan hasil penelitian dan pembahasan disimpulkan bahwa 14 butir soal matematika model PISA menggunakan konteks Jambi yang dikembangkan telah valid dan praktis. Kevalidan soal diperoleh dari proses validasi pada tahap expert reviews dan one to one. Pada tahap expert reviews para pakar menilai dari segi konten, konstruk, dan bahasa, sedangkan pada proses one to one dilakukan untuk melihat kejelasan dan keterbacaan soal oleh siswa. Adapun kepraktisan soal tergambar dari tahap small group dimana semua siswa dapat memahami maksud soal dengan baik, sesuai dengan alur pikiran siswa, mudah dibaca, dan tidak menimbulkan penafsiran yang beragam. Karakteristik yang dibangun dalam pengembangan soal ini adalah perangkat soal yang dikembangkan memiliki ciri soal PISA dan menggunakan konteks Provinsi Jambi dan memiliki efek potensial. Efek potensial yang muncul berdasarkan analisis dokumen field test terhadap soal-soal yang dikembangkan di antaranya adalah mampu menarik minat dan memotivasi siswa sehingga merasa tertantang untuk menyelesaikan soal. Soal ini juga menjadikan siswa melibatkan berbagai kemampuan dasar matematika dan kemampuan berpikir kritis dalam penyelesaiannya.

Berdasarkan hasil penelitian dan kesimpulan disarankan hendaknya dapat menggunakan perangkat soal matematika model PISA menggunakan konteks Jambi yang telah dikembangkan ini sesuai dengan materi ajar untuk melatih kemampuan literasi matematis siswa atau sebagai alternatif dalam memperkaya variasi soal matematika yang diberikan kepada siswa.

\section{Daftar Pusaka}

Johar, R. (2012). Domain PISA untuk literasi matematika. Jurnal Peluang, 1(1), 30-41.

Kadir, K., \& Masi, L. (2013). Penggunaan konteks dalam pembelajaran matematika untuk meningkatkan keterampilan sosial siswa SMP. In Proceeding KNPM V Malang (pp. 786796). Malang.

Kertayasa, I. K. (2014). Achievement of Indonesian Student in Assessement By Using Online Mathematical Problems. In Proceeding the 2nd SEADR (pp. 162-171).

Kohar, A. W. (2014a). Developing PISAlike mathematics tasks to promote students' mathematical literacy. In Proceeding the 2nd SEA-DR (pp. 14 26). Palembang.

Kohar, A. W. (2014b). Pengembangan soal matematika model PISA: sebuah alternatif langkah awal memperbaiki prestasi literasi matematika siswa Indonesia.

Kurniasih, A. W. (2011). Identification critical thinking stages of Students' mathematics education study program FMIPA UNNES for solving mathematics problems. In the Fourth National Conference on Mathematics Education (pp. 639-650). Yogyakarta.

Lange, J. de. (2007). Large-Scale

Assessment and Mathematics Education. In F. K. Lester (Ed.), 
Second Handbook of Research on

Mathematics Teaching and Learning (pp. 1111-1142). USA: Information Age

Publishing Inc.

Leung, A. Y., Chan, W., Tang, K., \& Chan, W. (2009). in the Past Twenty-Five Years in Hong Kong. Educational Research Journal, 24(1).

OECD. (2009). Learning Mathematics for Life: $A$ Perspective from PIS $A$. Paris: OECD Publishing.

OECD. (2013a). PIS A 2012 assessment and analytical framework: mathematics, reading, science, problem solving and financial literacy. German: OECD Publishing.

OECD. (2013b). PISA 2015 Draft Mathematics Framework, (March 2013), 52.

Rizta, A., Zulkardi, \& Hartono, Y. (2013). Pengembangan soal penalaran model timss matematika smp. Jurnal Penelitian Dan Evaluasi Pendidikan, 17(2230 240). Retrieved from http://dx.doi.org/10.21831/pep.v17i 2.1697

Stacey, K., Almuna, F., M., C. R., Chesne', J.-F., Garfunkel, S., Gooya, Z., Zulkardi, Z. (2015). PISA's Influence on Thought and Action in Mathematics Education. In K. Stacey \& R. Turner (Eds.), Assessing Mathematical Literacy. Switzerland: Springer.
Tessmer, M. (1998). Planning and conducting formative evaluations: improving the quality of education and training. London: Kogan Page.

The Cornerstone Tech Prep. (1999). Teaching Mathematics Contextually. Texas: CORD.

UNESCO. (2008). Developing culturally contextualised mathematics resource materials: capturing local practices of Tamang and Gopali communities; a report; 2008. Kathmandu: Lusha Press.

Wardani, A. K. (2014). Developing the Level Six PISA Like Problems for Enrichment. In Proceeding the 2nd SEA-DR (pp. 35-42). Palembang.

Widjaja, W. (2011). Towards Mathematical Literacy in the 21 st century : Perspectives from Indonesia. Southeast Asian Mathematics Education Journal, 1(1), 70-79.

Widjaja, W. (2013). The Used of Contextual Problems Support Mathematical Learning. Journal on Mathematics Education, 4(2), 151-159.

Zulkardi, Z. (2002). Developing a learning on realistic mathematics education for Indonesian students teachers. Doctoral dissertation. Enschede: University of Twente, Enschede. The Nederland. (Online). Retrieved Januari 7, 2015, from http://doc.utwente.nl/58718/1/thesi s_Zulkardi.pdf. 